\title{
Posthuman Conjectures: Animal and Ecological Sciences in Marie Darrieussecq's Dystopian Fiction
}

\section{Stephanie Posthumus}

Number 115, Winter 2020

Précisions sur les sciences dans l'oeuvre de Marie Darrieussecq

URI: https://id.erudit.org/iderudit/1067883ar

DOI: https://doi.org/10.7202/1067883ar

See table of contents

Publisher(s)

Department of French, Dalhousie University

ISSN

0711-8813 (print)

2562-8704 (digital)

Explore this journal

Cite this article

Posthumus, S. (2020). Posthuman Conjectures: Animal and Ecological Sciences in Marie Darrieussecq's Dystopian Fiction. Dalhousie French Studies, (115),

41-54. https://doi.org/10.7202/1067883ar

\section{Article abstract}

Despite being published over twenty years apart, Marie Darrieussecq's novels, Truismes (1996) and Notre vie dans les forêts (2017), share many features including their dystopian setting, urgent narrative tone, and themes of hybridity, corporeality and radical revelation. Deconstructing the boundaries between animal and human, nature and culture, human and machine, they invite the reader to move beyond anthropocentrism. In response to this invitation, I propose four posthuman conjectures, tracing the ethos of animal and ecological sciences in the two novels. First, I examine the ways in which the presence of non-human animal worlds requires imagining new subjectivities and writing embodied languages. Second, I move from the animal world to the machine cyborg who remains caught in the effects and affects of the techno-scientific complex in Darrieussecq's dystopian fiction. Third, I consider the space made in both novels for death and dying as a non-metaphysical phenomenon situating humans in an eco-evolutionary web. Last, I define writing as a form of (post)human technology that the novels use to reject the notion of human superiority and to illustrate language's capacity to imagine new, less-hierarchical paradigms.
This document is protected by copyright law. Use of the services of Érudit (including reproduction) is subject to its terms and conditions, which can be viewed online.

https://apropos.erudit.org/en/users/policy-on-use/ 


\title{
Posthuman Conjectures: Animal and Ecological Sciences in Marie Darrieussecq's Dystopian Fiction
}

\author{
Stephanie Posthumus
}

? literature's traditional focus has been human drama, characters, and plot, how can literary texts narrate non-human worlds as diverse and varied as animal and machine subjectivities, mountain and plant thinking, bacteria and nanobot agency? The term "conjecture" nicely captures the imaginary work that is needed when literature attempts to bridge the human/non-human world. A literary or poetic rendering of the non-human world is necessarily based on incomplete information. As Thomas Nagel explains, we can never know what it is like to be a bat, but this does not mean we cannot extend the possibility of conscious experience to the bat. Without claiming that all of Marie Darrieussecq's work is a form of conjecture, I propose the term as a way of thinking about the role of animal and ecological sciences in two of her novels, Truismes (1996) and Notre vie dans les forêts (2017).

Whereas the cognitive sciences clearly influence Darrieussecq's representation of the mind as brain (Kemp 429-33), references to animal and ecological sciences are few and far between in her fiction. The ethos of these scientific discourses has, however, clearly infused her writing about animal-human relations and human-nature interactions. Animal sciences like ethology have helped drive the critique of anthropocentrism, while ecological sciences have revealed to what extent humans are dependent on their environment and other organisms within it. Rather than measuring the "accuracy" of Darrieussecq's novels with respect to these sciences, I will trace the undoing of animal/human, nature/culture, and human/machine binaries that these sciences have helped bring about. It is in the sense of an "appréhension scientifique et poétique" (Simon, "Déterritorialisations" 22) that I will explore four posthuman conjectures related to animals, machines, and environments in Darrieussecq's writing.

It may seem problematic to focus solely on two of Darrieussecq's novels. And yet Truismes and Notre vie dans les forêts have much in common and are quite different from her other novels, despite the twenty-one-year gap between them. Both ask how one can survive in a future dystopian world. Both recreate a political climate in which people are controlled, contained, reduced to objects to be bought, sold, and abused. In Truismes, the narrator transforms into a sow to escape this oppressive society, while in Notre vie, the narrator flees to the forest where she and a small group of escapees try to hide from the allseeing eye of surveillance technologies. In both novels, the narrators are writing their story under extremely distressing conditions, emphasizing their material and physical difficulties as they warn the reader of such eventual societies ${ }^{1}$. Both novels use typographic features such as italics to point to the hegemonic effects of language and both recreate the quality of verbal speech by addressing the reader directly and repeating stock terms. They are told by first-person narrators who nevertheless avoid first names to protect their identities, but also, more importantly, to complicate notions of the "I" as an individual, nameable self".

1 During an interview given at the Salon du livre in Montréal on November 18, 2017, Darrieussecq spoke of the similar sense of urgency she had when writing these two novels because of the political climate in France. Notre vie dans les forêts was written during the 2017 French presidential campaigns when the popularity of the Front National party leader Marie Le Pen was at its peak. Twenty-one years earlier when Darrieussecq was working on Truismes, Jean-Marine Le Pen's party won three municipal elections in 1995. Clearly, the rise of the far right in France has influenced Darrieussecq's creation of fictional dystopian societies.

2 In Truismes, the narrator does not reveal her name, making it difficult to refer to her as anything other than "the narrator". While some literary critics have chosen to call her "Pig" (problematically glossing over the fact that she is female), I will use the somewhat awkward hyphenated expression "narrator-sow" and so keep the 
This air de famille is supplemented by a kind of call and response between the two novels: how does the non-human animal create poetic possibilities that are not available to the posthuman clone? What affects and emotions are associated with the processes of becoming-animal compared to becoming-machine? How does the biological-organic imaginary intersect with the "techno-teratological imaginary" (Braidotti 64) in the space of the forest where both narrators write their story? Taking up these questions in my article, I will tease apart the multiple threads of the posthuman as critical theory, as social reality, and as fictional creation in these two novels ${ }^{3}$.

\section{Posthuman Conjecture \#1 - Non-human animal worlds require imagining new subjectivities and writing embodied languages.}

Despite Ludwig Wittgenstein's claim that if a lion could speak, we would not be able to understand him, animal sciences have been working to close the gap between the human and the animal since the early 1950s. Jakob von Uexküll did much to bring about this paradigm shift by asking how animals have their own worlds. In opposition to behaviourist science (according to which animals instinctively react to various stimuli), von Uexküll proposed a bio-semiotic approach that looked at how other sentient organisms experience the world through their perceptive experiences. In A Foray into the Worlds of Animals and Humans, von Uexküll describes the inner experience of animals as diverse as a tick, a crab, and a dog, in order to demonstrate that "for everything a subject perceives belongs to its perception world [Merkwelt], and everything it produces, to its effect world [Wirkwelt]" (42). The result of these perceptions and effects is the organism's umwelt or environment. Rejecting René Descartes's reductionist view of animals as machines sans âme, von Uexküll developed a rich understanding of animal subjectivities and their multiple environments. No longer was there a single "objective" perspective for producing scientific knowledge about animals, since humans, too, were immersed in their specific materialsemiotic umwelt.

This regard for animals as perceptive beings with their own unique ways of constructing a world permeates the story of a narrator-sow in Truismes. When she is in animal form, smell and taste replace sight as the most dominant senses for creating a world; a horizontal rather than vertical body position situates her centre of gravity lower than adult humans; her experience of space changes because of her body's weight distribution; and time moves forward in fits and starts rather than flowing evenly. The descriptions of these experiences undermine an anthropocentrism propped up by the thesis of human exceptionalism (standing upright, sight, etc.). Imagining a sow's umwelt does not mean, however, drawing on as much scientific information as possible. The reader does not learn, for example, that sows have oestrus and not menstrual cycles. Instead, the novel focuses on perception in order to express an intense coming-into-a-body that opens out to a broader "interanimalité" (Simon, "La plongée" 82), the site of new poetic experiences and languages. Whether the reader feels a sense of empathy for the narrator-sow and connects this to the bodies of industrial livestock is beyond the scope of my article. It is the novel's

emphasis on her hybridity. In Notre vie, the narrator discloses her fugitive name "Viviane" but she only uses it twice when she is teaching her clone twin Marie to speak $(13 ; 164)$. She claims that her real name is "Marie" but only uses this name once, adding "évidemment" and "il faut suivre" (13). Given the confusion of calling both characters "Marie", I will use the expression "narrator-clone" despite the fact that it does not address the theme of the doubling of self in the novel. It would be possible to call the narrator "Viviane-Marie" but this would place the emphasis on duplication rather than hybridity.

3 While N. Katherine Hayles theorizes the posthuman with respect to the information era and the rise of computer technologies (2-4), Rosi Braidotti defines the posthuman in terms of the nature-culture continuum and an understanding of matter as self-organizing (2). In this article, I will draw on both of these theories in order to examine the ways in which Darriessecq's two novels undo the concept of the human as an autonomous, selfdefining and self-determining subject. 
use of an ethological paradigm for representing and regarding animal worlds that I want to emphasize.

Glimpses of this paradigm can be found in Notre vie, but they are not fully developed into animal worlds. In a future in which humans have discovered how to create life through reproductive cloning, it is not surprising that animals, too, are subject to these processes. In the narrator's world, de-extinction (also called resurrection biology) has been perfected, so that zoos have specimens of previously extinct animals such as the woolly mammoth and the Tasmanian tiger ${ }^{4}$. Fascinated with the mammoth's bulky mass and weighty movements, the narrator describes a subjectivity that is unlike her own. She nevertheless concludes that zoos are "musées de la disparition" (73). Cloned domestic dogs do not fare much better. Even though the narrator insists that her cloned pet whippet is "un vrai chien", "un vrai animal non-humain" (70), "un vrai chien organique" (110), she does so largely in order to refute her boyfriend's view of all dogs as purely mechanical, driven by instinct, incapable of learning anything new ${ }^{5}$. It is not until the narrator escapes to the forest, where she encounters dogs who are born "sans usinage ni rien" (71) that she begins to question the practice of keeping and naming dogs. Observing the behaviour of dog packs in the forest, she speculates about a canine-specific umwelt in which dogs perceive "un groupe d'animaux humains, reconnaissables chacun à [son] empreinte olfactive" (71).

Despite von Uexküll's careful attention to specific animal worlds, he does not consider the constraints placed by human environments on an animal's capacity to construct its umwelt: the tick in the forest is compared to the domestic dog's perceptions and effects, without asking to what extent the dog's experience is limited by humans. Nor does von Uexküll ask about the ethics of keeping animals in order to study them in this way $^{6}$. In both Truismes and Notre vie, human society is seen as severely limiting animal worlds. City squares and parks provide only a temporary place for becoming-animal in Truismes, while the urban cloned animals in Notre vie are reduced to what John Berger has called "living monuments to their own disappearance" (24). Even the unexpected arrival of a homing pigeon with a message warning the narrator-clone - "Déprogrammez. Ça crève les yeux" (132) - does not undo the impression that animal umwelts have been radically modified in urban environments?

Both novels highlight the ways in which animals are caught within the fabric of our social structures and systems. But they do not propose a return to wild unmodified nature or a radical animal ethics. On the contrary, they reveal such ideas as constructs to which there is no return. At the end of Notre vie, the narrator juxtaposes two images: on the one hand, a reader coming across her "cahier dans la forêt" (186) after her death and reading it from front to back; and on the other, a group of elephants revisiting the site of a dead family member's bones, carefully handling "ces morceaux blanchis" and then leaving, "lourds et

4 Once again, Darrieussecq seamlessly weaves into her narrative a reference to current scientific research. Biologists such as Professor George Church at Harvard University are using cutting-edge genetic splicing technology like CRISPR to "resurrect" the woolly mammoth (see Church's "Woolly Mammoth Revival" website for more information).

5 I question how seriously the narrator can be taken when she speaks of "un vrai chien", "un chien organique", in opposition to "un chien-robot" (110). First, the narrator's insistence creates a sense of ironic distance. Second, the opposition between real and robot pets brings to mind an important intertextual reference. In Philip Dick's classic science fiction text Do Androids Dream of Electric Sheep? (1968), the main character makes a similar distinction between "real" and "mechanical" animals, but this distinction is broken down over the course of the novel. I will come back to the role of irony in Darrieussecq's writing in a later posthuman conjecture.

6 A similar critique has been made about ethologist Konrad Lorenz's work with graylag geese that led him to discover the principle of imprinting. A more sympathetic reading of this kind of "trans-species communication" can be found in Vinciane Despret's "The Bodies We Care For: Figures of Anthropo-Zoo-Genesis".

7 At the same time, the narrator is finally able to join the other escapees in the woods thanks to the help of these "liminal" creatures: the pigeon arrives with the warning message that the narrator heeds, and a feral dog later leads her to the escapees' hiding place in the woods once she has left the city. Even if their role is quite minor, these animals inhabit an important symbolic space in the novel. 
pensifs, contemplant le monde de leurs petits yeux mélancoliques pour ceux qui ne le voyaient plus" (188-89). In addition to referencing ethological knowledge about elephants' grieving practices and reducing the gap between animal and human cultural practices, these final lines create a strong sense of loss. The reader wonders how to reconcile the individual narrator's death with the disappearance of so many animal worlds and cultures because of anthropogenic climate change. Whereas Truismes cautiously celebrates the non-human animal as a figure who finds her voice in a dystopian society, Notre vie warns the reader that the posthuman is and will be a time of intense mourning.

Narrating animal worlds does not mean trying to recreate some kind of "speaking sow" or "dog-language" in Darrieussecq's novels. In Truismes, the narrator expresses her experience of coming-into-an-animal body using a style rich with imagery and metaphor: "Les truffes avaient la saveur des mares quand elles gèlent, le goût des bourgeons recroquevillés qui attendent le retour du printemps, le goût des pousses bandées à craquer dans la terre froide, et la force patiente des futures moissons. Et dans mon ventre il y avait le poids de l'hiver, l'envie de trouver une bauge et de m'assoupir et d'attendre" (139-40). In contrast to her use of truisms about the status of women, patriarchal norms, and the benefits of cosmetics, the narrator-sow develops a poetic voice to describe the contours, perceptions, and affects of her new body. As Anne Simon explains, literary language captures animal worlds not when it seeks to be most representational, but when it features "rythmes, styles, allures, élans, surgissements" ("Qu'est-ce que la zoopoétique?" 124). In Notre vie, the examples of such rhythms, styles, and emergences to narrate animal worlds are few and far between. There is however a telling example when the narrator uses the word "joy" - the only time the word appears in the novel - to describe the dogs running free in the forest: "Dans la forêt, nos chiens courent. Courent à toute vitesse. Joie !" (71). This short single paragraph contrasts the lengthy sentence structure of the narrator-sow's sensorial descriptions in Truismes. But the point is not to switch to a more anthropomorphic mode in place of the previous text's poetic style. Rather, the narrator-clone's narrative magnifies and condenses the oral components of Truismes in the glimpses it offers of animal worlds.

Zoopoetics has emerged as a way of studying the expression of non-human animal subjectivities in literary texts. In comparison to animal studies, it focuses more specifically on literary and cultural artefacts and so clearly overlaps with literary animal studies: "Une approche zoopoétique oriente vers des études animales littéraires focalisées sur les formes et les écritures (rythmes, phrasés, figures de style, points de vue, constructions narratives, etc.), tout en étant adossées à un socle pluridisciplinaire" (Simon, "Qu'est-ce que la zoopoétique?" 117-18). Motivated by an ethical concern for animals and attentive to new discoveries about animal subjects, zoopoetics is also, Simon adds, a zoopolitics. Darrieussecq is no stranger to the socio-political issues of today's contemporary society and is clearly working to invent a language to help the reader "habiter le monde" (Simon, "Qu'est-ce que la zoopoétique?" 22). This embodied language requires, however, coming to terms with the radical effects of research currently being done in biotech industry and the medical sciences on different kinds of bodies. If, like Simon, we take "zoo" to be derived from the Greek zoôn which refers to life more generally ("Qu'est-ce que la zoopoétique?" 122), we can ask how the posthuman clone challenges the categories of zoopoetics. Is there room for a figure that is both organic and mechanical, part human and part machine, in a "poétique du vivant", a poetics of life/the living world? Or do we need a machine poetics, a "poétique de la machine", a "mécanopoétique" to analyze the expression of a life that is both organic and inorganic? These are exactly the questions that Notre vie dans les forêts is asking. 


\section{Posthuman Conjecture \#2 - Cyborgs break down binary thinking, even while remaining products of the techno-scientific complex and its dystopian affects/effects.}

Donna Haraway first theorized the concept of the cyborg from a socialist-feminist perspective in the early 1980s. Although she subsequently abandoned the utopian possibilities of the "cybernetic organism", as a "creature of social reality as well as a creature of fiction" (291), this figure remains extremely relevant for a posthumanism that seeks to break down the boundaries of the animal/human, the machine/organic, and the physical/non-physical. In opposition to transhumanism's devotion to the cyborg as immortal and immaterial, posthumanism insists on the animal and organic elements of this figure. It is in this sense that the narrator-sow in Truismes is a cyborg despite the fact that there is very little mention of technology in the novel. Medical science exists not to further the quest for immortality, but rather, to police female bodies, especially with respect to their fertility ${ }^{8}$. Notre vie, on the other hand, fully explores the figure of the cyborg as a hybrid of living tissue and mechanical parts and as the product of techno-scientific advances. Yet the novel cannot be reduced to a dystopian affect in the face of such changes. According to Haraway, the cyborg imagery can be a way out of universalizing theories about human nature and a way of engaging with social relations of science and technology from a feminist perspective. It is with these possibilities in mind that I will examine the multiple cyborg models in Truismes and Notre vie.

The narrator's story in Notre vie centres on a plot twist that undoes much of the human/machine binary that had been constructed earlier in the novel: the narrator who believed she was a human being discovers that she is a clone, an "organ receptacle" for her human "original". The effect of this discovery on the narrator emphasizes a radical decentring of the human "I" perspective as she compares herself to "juste un surgeon périphérique" (182) and her human original to a souche (176). At the same time, this comparison infuses the cyborg figure with images of vegetal, organic processes. As the narrator herself notes, the term "clone" is derived from the Greek word for "jeune pousse" (103). Moreover, human clones are produced, like plants, through asexual reproduction, that is, with the genetic material from a single adult donor. They still require, however, unlike plants, a surrogate mother willing to carry the egg in her womb until birth (in this way, a woman never gives birth to an exact genetic version of herself). Without condoning human cloning, the novel undermines the artificial/natural and human/non-human divisions that often motivate debates about this new technology ${ }^{9}$.

The status of "sleeping clones" blurs these lines even further. While the narrator-clone fully participates in a social, professional, and personal life, her genetic twin, Marie, is kept in a constant comatose state in a "Centre de repos". These "moitiés" (halves), as they are called, are treated as bodies with no will, no consciousness, no rights. According to the medical staff, they are non-persons (85). And yet the narrator resists such terminology. For her, Marie's eye movements when sleeping are proof of her capacity to dream, whereas the doctors speak only of muscle spasms and the psychologists of "décharge neuroélectrique" (88). The narrator challenges this reductionist, deterministic explanation by describing how she begins to dream Marie's dreams, suggesting the existence of phenomena unexplainable

8 See for example the narrator's experiences at a medical clinic where she undergoes an extremely painful curettage for a (mis)diagnosed pregnancy and is chastised for her misshapen uterus after being subjected to a "hystérographie" (32).

9 The novel combines two kinds of human cloning: therapeutic and reproductive. While biotechnology has been advancing in the field of therapeutic human cloning - that is, cloning human cells for use in medicine and transplants - reproductive human cloning is not legal nor is it even biologically possible. Darrieussecq is, however, not the first to imagine the ethical dilemmas that will arise if therapeutic reproductive cloning does become a reality. Science fiction has dedicated many pages of writing to explore what such a world might look like. From Aldous Huxley's Brave New World (1932) to Kazuo Ishiguro's novel Never Let Me Go (2005), human cloning occurs largely in dystopian societies. 
by science and reason alone. In addition, her description of Marie dreaming, "comme les chats" (86), reveals a larger questioning about what has a mind, what can think, and what is deserving of our empathy and moral compassion. Animal-plant-machine differences are broken down by clone experiences of dreaming, intentionality and consciousness.

This does not mean difference is erased between forms of living beings. When the "sleeping clones" are brought into the woods and awoken by their rescuers, the narrator is disappointed by their learning capacities. Although she first sympathetically compares them to "poulains nouveau-nés" (124) and "une bande de babouins" (125), she goes on to critique their preference for frolicking in the woods, playing, hunting, and having sex. She ends up emphasizing human/clone difference when she asserts that awoken clones can never fully develop into human beings: "On ne peut évidemment pas les prendre pour nous, qui avons accumulé tant d'expériences, subi tant d'épreuves, vaincu tant d'obstacles. [...] Aucun sens politique, aucun désir métaphysique, aucun élan vers l'avenir. Tout au présent" (124-26). And yet when the narrator discovers that she too is a clone, the division is no longer between human and clone, but instead between socialized and unsocialized clone. The novel thus emphasizes the role of social environment in human development. It is not whether one is born from sexual reproduction or not that makes one human; it is whether one participates actively in human society and culture.

For Haraway, the replacement of sexual reproduction with asexual replication was one of the feminist utopian possibilities of the cyborg figure. No longer needed for "making babies", women would be free to undo a whole host of other hierarchical systems such as biological determinism, white patriarchy, and capitalist lines of production. As critics of Haraway pointed out (and Haraway herself later realized), the cyborg figure was unable to maintain its subversive power in the face of militarist capitalism. Hypersexualized in Hollywood films, the female cyborg did not in fact disrupt patriarchal gender politics. As automatized labour, the cyborg has not slowed the drive for profit or improved worker conditions; on the contrary, it has displaced human labour and increased social inequalities. In the military, cyborgs are being developed as killing machines rather than teaching humans to be more empathetic. It is for these reasons that Haraway abandoned her cyborg myth and turned instead to the framework of (non-human animal) companion species ${ }^{10}$.

The promise of the cyborg as feminist future utopia plays out quite differently in Truismes and Notre vie. In the former novel, the narrator-sow's incapacity to reproduce because of her hybrid couplings (with male humans, male boars, and a werewolf) tempers the dystopian affect of the cyborg figure. Despite her sorrow upon losing her young, the narrator-sow is free to write her story in the woods. As a human-animal cyborg, she can engage in the "replication of texts" rather than the "reproduction of individuals" (Haraway 313). In Notre vie, women continue to carry the burden of childbearing and caregiving. The narrator's mother is a surrogate, carrying the implanted foetus of both the narrator and Marie. Replication has not broken the chains of patriarchy in an era of cloning because "real" human wombs are still required. The narrator, however, represents a cog in the machine as she escapes to the forest and does not have any children of her own. Even if other clones can be reproduced from the same genetic material, the narrator is no longer "available" for organ transplants. Without fully subverting issues related to gender and sex (heteronormativity), both novels disrupt the reproductive paradigm that places the onus on women to keep the human species alive ${ }^{11}$.

10 See for example Le Monde's "Dans la tête des robots" (Hors-série n60, 2018), Eyal Press's "The Wounds of the Drone Warrior" (New York Times) and Sharon Riley's "Rise of the Robots" (The Walrus).

11 Amaleena Damlé adopts a more affirmative assessment of techno-, posthuman bodies in Darrieussecq's work. She asserts that such a body "resists traditional feminine stereotypes" (313), producing an "ironic manoeuvre" to undo "particular codes of femininity" and concludes that the posthuman body is "alive with unending possibilities" (316). 
Once the narrator learns that she too was cloned, she begins to question her assumptions about what it means to be human. If clones who have experiences, face hardships, and overcome obstacles can be human, what is the status of robots who participate in human society? At first, the narrator insists on the difference between human and artificial intelligence, repeatedly pointing out the difficulty robots have in understanding figures of speech like metaphor. One of the main sources of humour in the novel are the word-associations that robots are taught in order to better parse language and meaning. And yet the lines between kinds of intelligence are not so cleanly drawn. The narrator wonders if the medical staff in the "Centre de repos" are robots and never does find out whether they are or not. This example suggests that artificial intelligence will become less and less identifiable as "artificial". The narrator goes so far as to wonder if she, too, is not a robot because of the implant that was placed in her brain, a boite cranienne, to control her pain after one of her transplant operations: "Robot comme les autres. / Je me lasse. / Vite" (185-86). She imagines that this brain implant will continue to send out signals long after her body has decomposed, keeping part of her "self" alive indefinitely into the future. Once the machine penetrates the mind and its thought processes, there are no more boundaries between "them" and "us" 12 .

But the narrator is not advocating for acceptance. The fear she feels when thinking about the "life expectancy" of her brain implant contrasts with her matter of fact description of the body's aging processes: "Toutes nos cellules se sont auto-remplacées. Tous nos tissus se renouvellent plusieurs fois dans notre vie. Notre cœur et notre cerveau, je crois que c'est plus lent, mais la plupart des organes dans notre corps ont systématiquement moins de dix ans et continuent de se régénérer sans cesse" (183-84). Embodiment continues to be a source of positive affect in the face of techno-scientific advancement even if this means coming to terms with death or what posthuman theorist Rosi Braidotti calls "the destructive forces of zoe" (139). The most pressing issue in the face of such advancement is not whether clones are human or not, but how to resist being reduced to a "disposable body" (Braidotti 15) when "les $1 \%$ de super-riches [...] possèdent $99 \%$ de la richesse du monde" (Darrieussecq, Notre vie, 177).

This is made clear in the book's final footnote when the narrator addresses the implied reader directly: "Et ne croyez pas que je ne sois pas sûre de ne pas être une non-personne" (186). Having lost the rights over her own body, the narrator speculates about whether she still has the status of a person, and in doing so, decouples the notion of personhood from that of the human. At the same time, her use of four negative constructions in this sentence subtly references a point made earlier in the narrative: "[P] abuser des doubles négations" (53). In other words, the narrator is expressing her doubts about being a person in a coded language that a robot would not understand, at least not the robots of her generation. This reintroduces difference in a statement about nondifference. And if the readers understand the meaning of the final endnote, they can be reassured of their own non-robot status (unless, of course, they are of a more advanced robot generation).

\section{Posthuman Conjecture \#3 - Death and dying are key to experiencing ecological interrelatedness and evolutionary continuity.}

The expression "ecological sciences" in the main title of my article is something of a misnomer. Today, the more commonly used expression is environmental sciences. And yet I prefer "ecological" because it harks back to German zoologist Ernest Haeckel's early

12 The narrator further breaks down the differences between human-clone-robot when describing the parts of her body that serve as hardware devices. For example, her hand movements allow her to surf the Internet that "appears" in her mind, and her eyes to "blink" from one page to the next (129). In order to escape into the woods, she must first remove the tracking devices from beneath the skin behind her ear and in her wrist. She is able to "shed" these other bits of cyborg machinery, but not her brain implant. 
definition of ecology as the study of the relationships between an organism and its environment. Moreover, Haeckel's thinking about ecology was strongly informed by Darwin's evolutionary theory. Rather than look for evidence of specific ecological concepts in Darrieussecq's fiction such as niches, food webs, or climax communities, I will trace a more general ecological imaginary that refuses human exceptionalism and moves toward a postanthropocentric understanding of life. As ecocritic Timothy Morton explains:

Ecology is the latest in a series of humiliations of the human. From Copernicus through Marx, Darwin, and Freud, we learn that we are decentered beings [...]. Ecological humiliation spawns a politicized intimacy with other beings. [...] Such intimacy necessitates thinking and practicing weakness rather than mastery [...] and deconstructive tentativeness rather than aggressive assertion. (277-78)

In order to think through this "politicized intimacy with other beings", I will ask how Darrieussecq's two novels portray the relationship between organisms and their environment and how they explore the meaning of death and dying for a posthuman theory of life.

In the narrator-sow's interactions with her environment and other organisms, she becomes attuned to a larger ecological world. She speaks to her lover, Yvan, "de la steppe, de la neige d'été sur la taïga, des forêts gauloises, du Gévaudan, des collines basques, des bergeries cévenoles, de la lande écossaise, et de la pluie, du vent" (Truismes 128). Even though she has not personally experienced these different places, she imagines nature as providing habitats for a wide variety of living organisms. Her poetic description is not meant, however, to construct nature as harmonious and idyllic. When looking for food to sustain herself, the narrator-sow recognizes that death is just as much a part of nature: "Je sais aujourd'hui que la nature est pleine de contraires, que tout s'accouple sans cesse dans le monde [...]. Sachez [...] qu'il m'arrive souvent maintenant de fendre d'un coup de dents un petit corps de la nature, et que je n'en tire ni dégoût ni affectation. Il faut bien se procurer sa dose de protéines" (53-4). Becoming-animal allows the narrator-sow to experience ecological interrelatedness intimately and to inscribe herself in this evolutionary continuity.

While many critics have emphasized the role of the sea in Darrieussecq's writing, less attention has been paid to the forest. And yet it appears in both Truismes and Notre vie as the space in which an alternate kind of thinking can take place, in which social critique can emerge through writing. In Truismes, the narrator-sow describes her initial sensorial experience of the woods: "Je me suis approchée des arbres. C'était la première fois que je voyais des arbres aussi hauts, et qui sentaient si bon. Ils sentaient l'écorce, la sève sauvage ramassée à ras de tronc, ils sentaient toute la puissance endormie de l'hiver" (139). In Notre vie, the narrator-clone describes a similar immersion when she first escapes into the forest, but with an emphasis on sight and sound rather than smell:

La forêt était étourdissante. De toutes petites feuilles d'un vert très clair, d'un vert tellement naturel qu'il me semblait artificiel, le vert de quand on pense au vert $[\ldots]$ Et le fait de ne rien entendre dans l'oreille que le bruit du vent dans les arbres, et occasionnellement, oui, un oiseau. Étourdissant. Je vibrais. Je respirais. Pas de sollicitations, rien. Juste l'invitation du vent, des arbres et des oiseaux, et du soleil. (149)

Each narrator experiences the forest as a coming-back-into-body, as an opening out to the natural world after being contained and controlled in an oppressive, dystopian society. While advanced capitalism has treated forests as resources to be exploited and destroyed, they become places of dwelling in these two novels, or what Simon calls "espace habitable" ("Déterritorialisations" 22).

Given Darrieussecq's reputation for ironic distance, it may seem naive to posit the forest as habitat or place to live. It is true that the narrator-clone subscribes to some of the 
common tropes about the forest as "inquiétante," a place inhabited by wolves in fairy tales (50). But this social imaginary is inseparable from the political one being portrayed in the novels: the forest is also a place of exile from an impossible human existence. Living in the forest does not mean a return to the bon sauvage nor to some brute animal state; rather, it means creating a space for hybridity: "Je pense que ça nous définissait, comme animaux humains. La forêt. Les arbres" (50). In the forest, animal human forms coexist with other living organisms such as birds, turtles, boars, wild dogs, and trees ${ }^{13}$. The forest is also where the writer finds her voice and learns to write her life story. Upon her arrival in the forest, the narrator-clone asserts: "Je veux parler de notre vie dans les forêts" (35). The use of the plural noun "forests" evokes a broader literary aim of writing from a space that has not succumbed to capitalism's stranglehold on the social imaginary, a space that moves towards a postanthropocentric understanding of humans ${ }^{14}$.

In his article "Darrieussecq's Mind", Simon Kemp includes a footnote in which he briefly makes a case for a Darwinist reading of the author's work, citing "her focalization through animal minds as well as human ones" (432). While I wholeheartedly agree with Kemp, I have been shifting the focus from Darrieussecq's portrayal of mind and thought to her portrayal of human-animal-machine embodiment. As Kemp brilliantly illustrates, mind and body are inseparable in Darrieussecq's view. But I am more interested in how this biological, materialist view affects the notion of the body as embedded in the processes of evolutionary life. According to feminist philosopher Rosi Braidotti, a posthuman theory of death means coming to terms with the fact that lifeforms are temporary, ephemeral, in constant flux and change, while also critiquing the biopolitical forces that determine and control who lives and who dies.

Given that Darrieussecq's two novels portray extremely dystopian societies, it is not surprising that death and violence are omnipresent. There are however important differences in the perception of these threats. In Truismes, the narrator-sow does not critique the terrifying forms of necropolitics around her (for example, the violent removal of homeless people, the elimination of immigrants, the disappearance of most animals). But her narrative does highlight the vulnerability of these bodies made "disposable". In Notre vie, the narrator-clone is clearly aware of the biopolitical issues related to cloning: "Ils nous traitent comme du bétail, je me suis dit. Ils nous infantilisent au point qu'ils nous avertissent même pas de la procédure, même pas quand il s'agit de nos corps ! De mon corps !" (138; emphasis in the original). She also comes to the realization that the violence done to cloned bodies is a form of necropolitics; it shortens their life span and increases their suffering ${ }^{15}$.

13 Examples of the forest as a place of cohabitation for animal human forms can be found in both novels. When the "awoken clones" are taught to walk and to speak, they come into their human form: "On creusait leur cambrure d'humain, on leur faisait découvrir leurs voix" (13). A strikingly similar image of the human form emerging upright to speak is described at the end of Truismes: "[M]oi c'est pour retrouver ma cambrure d'humain que je tends mon cou vers la Lune" (149). Yet the point is not to associate verticality with human superiority, but instead to break down the rigid hierarchy between humanity and animality, pointing instead to the radical fluidity between lifeforms.

14 It is also important to note that the forest is not "pure nature"; it is instead a compromised space on the edge of society, never completely free from social control. In Notre vie, the sleeping clones are housed in an old castle turned medical institution outside of the city and protected from the woods around it by a large enclosure. The narrator speaks of the association this creates between the sleeping clones and the forests: "Le rythme de la marche me permettait de me concentrer à la fois sur Marie et sur les arbres, comme s'ils allaient bien ensemble" (101). Again, the novel closes the distance between the artificial and the natural, the cloned and the organic in the forest space, while refusing an idyllic nature-culture harmony.

15 Cloned animals also die young, as the narrator points out in her discussion of Dolly the sheep (122-23). This does not mean that death is not any less a part of the processes of life, however. As the narrator explains, her cloned pet whipped died "une mort naturelle" despite the fact that he was only six years old (131). While life may be created and controlled in the lab, it is still imbricated in the processes of aging and dying. 
In the end, the transhumanist dream of immortality does not eliminate death; rather, it leads to more inhuman treatment of all of life, human and animal, organic and inorganic. While the $1 \%$ who are rich enough to afford multiple clones for organ harvesting may live to be two hundred years old, the other $99 \%$ are victims of invasive and painful forms of biocontrol. As the narrator's life slowly slips away, she concludes bitterly that the mechanical bits and pieces of her body will outlive her. And yet she notes earlier in her narrative that a robot in her building also "died" during a particularly intense period of social control and surveillance (106). While it is true that mechanical matter does not pass from a living to a non-living state, the boundaries between such categories are breaking down. Death is no longer a "human prerogative" (Braidotti 130). However, the inhumanity with which human, animal, and clone lives are destroyed may very well be what continues to characterize Homo Sapiens: "Cette inhumanité qui est pour Deleuze un aspect de notre 'propre', il me semble que Marie Darrieussecq écrit avec/pour elle" (Simon, "Déterritorialisations" 25).

Both novels include an epigraph that frames the question of how killing makes humans inhuman(e). Truismes begins with a quote from late nineteenth-century Norwegian author Knut Hamsun's novel Hunger that describes a boar who realizes that his throat is being cut. When the narrator-sow narrowly escapes a similar fate at the end of the novel, the reader reflects on the ways in which humans prematurely put an end to non-human lives. No critique is given of such practices, but the narrator-sow offers a view of what it is like to be on the receiving end of such a death ${ }^{16}$. In Notre vie, the advent of human cloning increases the capacity for inhuman(e) exploitation. And yet the epigraph from Russian twentieth-century poet Sergueï Essenine refers to a decision not to kill: "Je n'ai pas fusillé le malheureux au fond des caves." This choice is echoed by the narrator-clone when she explains that they had to find a way to live with their "awoken clones" since they certainly could not kill them (36). She then quotes Essenine as if to reassure the reader. But this human(e) choice is complicated by the narrator's next words: "Bien sûr nous sommes armés. Nos robots piratés sont des armes" (37). As part of the escaped community living in the woods, the robots represent a further problem in the posthuman predicament as killing machines. In the end, the narrator dies a "natural" death in the sense that her cells are no longer reproducing at the necessary rate for embodied human life to continue. But it was the removal of her vital organs such as her kidney and part of her lung that precipitated her death. While Truismes represents killing as the taking of a life at a single moment, Notre vie narrates a life that was already a kind of killing from the moment it $\operatorname{began}^{17}$.

\section{Posthuman Conjecture \#4 - As (post)human technology, writing destabilizes anthropocentrism, and (under)mines irony's double-edged power.}

In "L'Animal que donc je suis (à suivre)", Jacques Derrida begins the careful work of deconstructing human exceptionalism by questioning the assumption that humans alone are capable of writing. Understood less anthropocentrically, writing refers to a set of practices that include tracks making and erasing themselves: "Qu'une trace puisse toujours, elle, s'effacer, et à jamais, cela ne signifie pas du tout, et c'est là une différence critique, que quelqu'un, homme ou animal, je le souligne, de lui-même effacer ses traces" (284).

16 This reading is complicated by the fact that Knut Hamsun was a Nazi sympathizer during WWII, and by the fact that the book is banned when the narrator-sow draws attention to its "subversive" content, i.e. its representation of death from the boar's point of view.

17 To some extent, Notre vie illustrates the terrible existence of factory farmed animals who are raised in unbearable conditions only to be killed even more clearly than Truismes does. The narrator-clone evokes this reality when she speaks of "[1]e clonage des animaux non humains" as "l'abattage, ni plus ni moins" (74), yet she distances herself from this assertion by adding: "c'est ce qu'on m'a dit dans la forêt" (ibid.). 
Derrida does not however extend this thinking about writing to the world of machines ${ }^{18}$. And yet we can ask whether such an extension may one day be possible as humans and machines become more and more seamlessly integrated. What is gained when the autobiographical animal's tracks are erased? What is lost when the cyborg learns to leave its mark in the form of writing? How can irony temper the gains and losses of writing as a (post)human technology?

In Truismes, the narrator-sow begins by using a play on words to refer to her unreadable handwriting - her "écriture de cochon" (11) - and to hint at her porcine transformation. Interpreting the text as written by a human-sow hybrid starts the work of destabilizing anthropocentrism. This is the kind of posthuman writing of which Braidotti speaks when she describes "thinking beyond the bounded self" as the "ultimate gesture of de-familiarization" (136) ${ }^{19}$. But this is not the only way of following the autobiographical animal in Darrieussecq's novel. Despite being witness to horrible forms of violence, the narrator-sow does not denounce such actions as misogynist or racist or speciesist. Her lack of explicit critique is not, however, proof of an "animal" innocence or naïveté, nor of an animal's supposed lack of moral system. This is not, I would argue, how animal traces are left in the novel. To follow the autobiographical animal means examining the gaps in writing: when does language fail to represent the alterity of non-human life? When does the novel skip over key socio-political events that give rise to a new dictatorship? When does the narrator-sow not convey her experiences with other animals? When does she not try and describe her interactions with the non-human world? In responding to these questions, it is possible to "hear" a different kind of animal silence in the novel, not because animals are unable to communicate, but because this silence makes room for a form of writing as erasing rather than marking.

At the same time, it is important to acknowledge the ways in which the novel (over)emphasizes writing as a human endeavour. The narrator must "retrouver [s]a cambrure d'humain" (149) in order to write, and she is often hampered by the mud, the cramps in her hand, and the lack of light (11). Overcoming material conditions and learning to stand upright are part of the traditional anthropocentric narrative about human evolution and progress. Moreover, there is an urgency in the narrator's writing that leaves little space for the animal's silence, understood as the gaps, inconsistencies and inadequacies of human language. The text has no chapter breaks, as if written d'un seul trait, with white space being used here and there to break up the continuous flow of words. Even the fact that the narrator-sow is writing in the forest can be interpreted as an intertextual reference to further recreate the fairy tale world of anthropomorphized pigs and werewolves.

While such a reading fits well with a 1980s and 1990s postmodernist aesthetics, it does not do justice to the ways in which the novel leads out of the "prison-house of language" (Jameson). According to Haraway, "cyborg writing is about the power to survive, not on the basis of original innocence, but on the basis of seizing the tools to mark the world that marked them as other" (311). If we remember that the narrator is never fully sow nor fully human, her cyborg writing constantly resists being mapped onto one lifeform or another. The use of italics in the novel creates a critical distance between a literal and an ironic use of misogynist discourse, undermining the language that had been used to mark

18 The closest Derrida gets to thinking about machine writing is when he speaks of "un animal de lecture et de réécriture" that he is tracking: "Cet animal-machine a un air de famille avec le virus qui obsède, même s'il n'envahit pas tout ce que j'écris. Ni animal ni non-animal, ni organique ni inorganique, ni vivant ni mort, cet envahisseur potentiel serait comme un virus d'ordinateur. Il logerait dans un opérateur d'écriture, de lecture, d'interprétation" (289).

19 For additional studies of Darriessecq's cyborg writing, see Amaleena Damlé's “'Truismes”: The Simulation of a Pig"; Lorie Sauble-Otto's "Writing to Exist: Humanity and Survival in Two fin de siècle Novels in French (Harpman, Darrieussecq)" and Michèle Schaal's "Jusqu'au-boutisme du paradoxe : Truismes de Marie Darrieussecq" (48-98). 
the narrator-sow as objectified, commodified, animalized, and otherized ${ }^{20}$. Finally, the material conditions in which she writes signal her entanglement with other lifeforms rather than a way of overcoming them. The reader is left with her own wound after being exposed to irony's double-edged power that is capable of both exposing and appropriating anthropocentric, misogynous, inhumane treatment of vulnerable bodies.

In Notre vie, the act of writing is also used to destabilize anthropocentrism. The reader is first lead to believe that the narrator's sense of responsibility towards her clone comes from her humanity; the narrator is "fully human" despite her various implants. But in the last fifteen pages of the novel, this distance is destroyed when the narrator discovers that she, too, is a clone, an organ receptacle for the same human as Marie: "Ça demande une révolution mentale, vraiment, de ne plus se voir au centre" (182). Identifying with the narrator as a human up till that point in the story, the reader is forced to undo her assumptions about what distinguishes the human from the posthuman. And by appealing to the reader's sense of sensibility towards a dying lifeform, the novel maintains a sense of connection to that which is becoming other.

In many respects, the novel raises the spectre of the autobiographical machine narrating his/her/their own life story. On the one hand, the narrator connects the act of writing to automatic hand movements: "Peut-être que je remue un tout petit peu la main, le bras, et que ça écrit encore, presque sans moi" (187). She wonders to what extent her brain implant is controlling what she thinks and says, breaking down the notion of a single self whose thought processes are rooted in biological functions. On the other, the narrator interrupts the story more and more often to refer to her physical state, to feeling cold, hungry, tired - and so reminds the reader that she is an embodied lifeform, and not a "robot humain" (18). Unlike transhumanist's utopian hope of transcending biological forms, Darrieussecq reveals a posthumanist thinking that constructs subjectivity in terms of hybridity and embodiment: "The posthuman subject is an amalgam, a collection of heterogeneous components, a material-informational entity whose boundaries undergo continuous construction and reconstruction" (Hayles 3 ). This definition aptly describes the eclectic collection of socialized clones, newly awoken clones and hacked robots to which the novel's title refers using the first-person plural adjective - "notre vie".

Both Truismes and Notre vie push the reader to move beyond her anthropocentric views of the world, one in the direction of the non-human ecological animal and the other in the direction of the dying posthuman clone. Yet they both trouble a too easy identification between the reader and the narrator. They do so by using irony, but also by giving the reader clues to interpret the narrator's situation before the narrator herself acknowledges what's going on. This narrative structure creates an uneasy relationship between the reader and the narrator. For example, in Notre vie, the narrator speaks of her eye being taken out and not understanding why Marie's eye has not also been removed. The reader, on the other hand, has most probably already concluded that organs are being harvested from and not transplanted into the narrator's body. This position with respect to the narrator is complicated by the fact that both narrators interrupt the story to speak directly to an implied reader. In Truismes, the narrator advises the reader to find a "nice man" and get married as if she still adhered to the conservative and patriarchal moral system of the dystopian society she has fled. In Notre vie, the narrator asserts that she is going to tell the reader about living in the forest and yet she offers very few details about such a life, recounting instead the events that led up to her escape. The real reader becomes aware of the distance between

20 The incongruity of animal metaphors is highlighted in the novel when the narrator-sow is referred to as "les chattes en chaleur" (39; emphasis in the original), "une vraie chienne" (40; emphasis in the original), and "grosse vache" (61). In addition to naming the wrong animal (the narrator is a sow, not a cat, dog, or cow), these metaphors reveal the double subjugation of women and animals that is often at work in these kinds of derogatory insults (see Joan Dunayer's "Sexist Words, Speciesist Roots"). 
herself and the implied reader, but also between herself and future readers of these two novels.

But the point is not to get lost in a hermeneutic hall of mirrors. Darrieussecq has repeatedly articulated her desire to bring her writing to bear on today's socio-political reality, asking how we can intervene and respond in the face of new technological advancements. Haraway offers one way of thinking through the reader-narrator relationships in these novels:

Writing is pre-eminently the technology of cyborgs, etched surfaces of the late twentieth century. Cyborg politics is the struggle for language and the struggle against perfect communication, against the one code that translates all meaning perfectly, the central dogma of phallogocentrism. That is why cyborg politics insist on noise and advocate pollution, rejoicing in the illegitimate fusions of animal and machine. (176)

By hiding information about a key life event, by creating a portrait of the implicit reader, by providing clues that may or may not be interpreted correctly, Darrieussecq's novels perform the struggle for language. They do so not in order to pull the reader further into the rabbit hole of literary study, but in order to eject her into the real world of cyborg politics, to keep her "cerveau [...] malléable" (Notre vie 43) against the onslaught of "perfect communication" and the "central dogma of phallogocentrism". Such malleability is, however, vulnerable and precarious; it implies "weakness and not mastery" (Morton 278), the acceptance of hybrid, embodied forms that are always in various stages of lifedeath.

If there is a lingering humanism in Darrieussecq's writing, it can be found in the gap between the organic non-human animal and the mechanical, robotic machine. This gap does not, however, reinstate the theory of human exceptionalism nor propose to redefine human nature holistically. Rather, this gap maps out the differences between the posthuman as critical theory, as social reality, and as fictional creation. While posthumanist thinkers propose that advanced technologies may one day bring about more human(e) interactions between humans and non-humans, the social reality of today's military and surveillance drones confirm the opposite. If there is hope to be found in Darrieussecq's lingering humanism, it is in the power of the imagination, in the posthuman as fictional creation, as a way of experiencing the world through the body of a hybrid human-sow and identifying with clones who are subject to biomedical interventions that bring them both life and death. If I may put forward one final conjecture, new posthuman scenarios will emerge from a transversal becoming-machine and becoming-animal, when artificial intelligence is modeled on animal intelligence (and not human intelligence), leading us out of our current (in)human(e) practices.

McGill University, Montreal

\section{WORKS CITED}

Braidotti, Rosi. The Posthuman. Cambridge, UK: Polity Press, 2013. Print.

Church, George. The Woolly Mammoth Revival. Revive \& Restore Project. $<$ http://reviverestore.org/projects/woolly-mammoth/>. (Accessed 14 March 2018). Web.

Damlé, Amaleena. "Posthuman Encounters: Technology, Embodiment and Gender in Recent Feminist Thought and in the Work of Marie Darrieussecq". Comparative Critical Studies 9.3 (2012): 303-18. Print.

---. “Truismes': The Simulation of a Pig”. Dalhousie French Studies 98 (2012): 15-27. Print. 
Darrieussecq, Marie. "Autour de Notre vie dans les forêts." Interview at the 40e édition, Salon du livre. 18 November 2017, Montreal, QC.

---. Notre vie dans les forêts. Paris : P.O.L, 2017. Print.

---. Truismes. Paris : Gallimard, [1996] 2008. Print.

Derrida, Jacques. "L'Animal que donc je suis (à suivre)". L'Animal autobiographique. Autour de Jacques Derrida. Ed. Marie-Louise Mallet. Paris: Galilée, 1999. 251-301. Print.

Despret, Vinciane. "The Bodies We Care For: Figures of Anthropo-Zoo-Genesis.” Body \& Society 10.2-3 (2005): 111-34. Print.

Dick, Phillip, K. Do Androids Dream of Electric Sheep? New York: Doubleday, 1968. Print.

Dunayer, Joan. "Sexist Words, Speciesist Roots." Animals \& Women. Feminist Theoretical Explorations. Ed. Carol J. Adams and Josephine Donovan. Durham: Duke UP, 1995. 11-31. Print.

Haraway, Donna. "The Cyborg Manifesto." The Cybercultures Reader. Ed. David Bell and Barbara M. Kennedy. London: Routledge, 2001. 291-324. Print.

Hamsun, Knut. Hunger. Trans. Robert Bly. New York: Farrar, Straus and Giroux, [1890] 1967. Print.

Hayles, N. Katherine. How We Became Posthuman. Virtual Bodies in Cybernetics, Literature and Informatics. Chicago: U of Chicago P, 1999. Print.

Huxley, Aldous. Brave New World. New York: Harper Collins, [1932] 2006. Print.

Ishiguro, Kazuo. Never Let Me Go. London: Faber \& Faber, 2005. Print.

Jameson, Frederic. The Prison-House of Language: A Critical Account of Structuralism and Russian Formalism. Princeton: Princeton UP, 1972. Print.

Kemp, Simon. "Darrieussecq's Mind.” French Studies 62.4 (2008): 429-41. Print.

Le Monde. "Dans la tête des robots". Hors-série n60 (2018). Print.

Morton, Timothy. "Queer Ecology". PMLA 125.2 (2010): 273-82. Print.

Nagel, Thomas. "What Is It Like to Be a Bat?" Philosophical Review 83.4 (1974): 435-50. Print.

Press, Eyal. "The Wounds of the Drone Warrior". New York Times. 13 June 2018. $<$ https://www.nytimes.com/2018/06/13/magazine/veterans-ptsd-drone-warriorwounds.html $>$. (Accessed 14 March 2018). Web.

Riley, Sharon. Rise of the Robots". The Walrus. 14 November 2017. $<$ https://thewalrus.ca/rise-of-the-robots/ >. (Accessed 14 March 2018). Web.

Sauble-Otto, Lorie. "Writing to Exist: Humanity and Survival in Two fin de siècle Novels in French (Harpman, Darrieussecq)". L'Esprit Créateur 45.1 (2005): 59-66. Print.

Schaal, Michèle. "Jusqu'au-boutisme du paradoxe : Truismes de Marie Darrieussecq". Une troisième vague féministe et littéraire. Les femmes de lettres de la nouvelle generation. Amsterdam : Brill, 2017. 48-98. Print.

Simon, Anne. "Déterritorialisations de Marie Darrieussecq". Dalhousie French Studies 93 (2010): 17-26. Print.

---. "Marie Darrieussecq ou la plongée dans 'les mondes animaux"”. Dalhousie French Studies 98 (2012): 77-87. Print.

---. Propos recueillis par Nadia Taïbi, “Qu'est-ce que la zoopoétique?” Sens-Dessous 16.2 (2015): 115-24. Print.

von Uexküll, Jakob. A Foray into the Worlds of Animals and Humans. Trans. Joseph D. O’Neil. Minneapolis: U of Minnesota P, [1934] 2010. Print. 